\title{
Leadership Experiences of Poultry Business Leaders in Ghana
}

\author{
Dr. Remy Nyukorong \\ Management Partners (GH) Wa, \\ Upper West Region, GHANA
}

\begin{abstract}
Over the past years, leadership has been studied extensively; however, scant research exists investigating the role of volunteer leaders in non-ranked leadership roles in for-profit membership-based organizations. This phenomenological research was aimed at exploring the lived experience of poultry industry leaders in leadership roles. Data were obtained through face-to-face, semi-structured interviews with 15 poultry industry volunteer peer leaders in Ghana. Participants described their experiences as leaders and the interview data were transcribed verbatim and analyzed utilizing the Moustakas' transcendental data analysis procedure. Based on the themes from the study, volunteer business leadership was defined as "an executive role performed by an individual or group of persons, who unreservedly devote time and talent contributing to the greater good of the industry, accepting challenges of greater responsibility particularly with regard to decision-making, and representing members with honesty and fairness." Eight core themes identified the main phenomenon and five personality characteristics of poultry industry leaders were identified. The current study provides significance to the discipline of leadership; with particular reference to the poultry business sector as well as to other agriculture-based associations to better focus on selecting, training, developing and retaining leaders.
\end{abstract}

Keywords: volunteer leaders, peer leadership, poultry business sector, Ghana.

\section{INTRODUCTION}

The poultry industry is a key contributor to the socio-economic development of Ghana through job creation and the improvement of food security and nutrition. Regardless of these contributions the poultry industry is plagued with many challenges and problems such as, increased competition, high input costs, diseases control, low prices, ever-changing global markets, interest groups questioning production systems, qualitative and quantitative inadequacy of water and feed issues, collapsing of processing plants, regulatory and policy issues that can hinder current production and competing visions for the future are factors providing challenges for the poultry industry (Adei \& Asante, 2012; Asare-Boadu, 2010; Darko, 2010; FAO, 2014; Oppong-Apane, 2013; Otoo, 2009; Sumberg, Awo, Fiankor, Kwadzo, \& Thompson, 2013; USDA, 2011).

Regulations, directives and certain production customs can be costly for producers to carry out, usually with marginal benefits. In an unpredictable industry influenced by the political considerations, there is no assurance ordinary poultry producers are safeguarded or their interests taken into account in the creation and implementation of new regulations. To keep the business running, the poultry industry needs the support and cooperation from both local and state authorities (FAO, 2014).

In order to represent the interests and needs of poultry producers to local and national law making bodies, a unified voice is important and voluntary association fellows will be tasked to provide the needed leadership. There are several individuals and bodies involved in grassroots matters (Adei \& Asante, 2012; Sumberg et al., 2013; Kellogg Foundation, 1993) including poultry industry and agrarian organizations.

The role of agrarian organizations is to focus on issues that will directly and indirectly affect the source of living of its members (Ragasa \& Golan, 2012). With no firm, committed persons in leadership roles, attaining organizational goals may be constrained. Followers are the life force of companies and their leadership, normally on a charitable basis, is required to help the company with establishing future goals and vision, and in decision making (Abaru, Kabuga, \& Masake, 2005; Barry, 2015). 
A study of grassroots leadership conducted by Kellogg Foundation (1993) described grassroots leaders are individuals who share specific characteristics to influence change, are inspired and compensated by their service and dedication. The research determined that when communities are genuinely purposeful regarding grassroots leadership numerous advantages result, including the following: many people get involved at all levels, new leaders are developed and have access to support, leaders continually grow and are renewed, fresh talent is grown for conventional leadership positions, and more of a grassroots viewpoint is present in profit and non-profit management.

Current research calls for more effective poultry industry leadership. Sumberg et al. (2013) studied the problems confronting the poultry industry and how the industry can find solutions to the illdefined problems to stay alive after several years drop in demand for poultry. Sumberg et al. (2013) recommendation for a robust poultry industry includes more suitable poultry business leadership.

Poultry business leaders today have the arduous task to be the mouthpiece of their industry in hard times (Field, 2008; Speer, 2008). This representativeness arises in the form of volunteers within the poultry industry, who offer to serve on boards or committees of business establishments, such as municipal or national poultry farmers associations. This volunteer position is crucial for the sustainability of the business and the capacity of the company to accomplish their objectives and mission (Barry, 2015; Mathews \& Carter, 2010). As enterprises become more conscious of volunteers as an important economic asset and how to effectively engage volunteers, companies are interested in identifying ways to improve staffing, training, retention and motivation (Handy \& Hustinx, 2009).

Leadership provides benefits for individuals within the organization. People who assume the role of serving on management committees devote themselves to contribute in a significant way and act as agents for change. The outcome of this volunteerism can be a greatly fulfilling experience. Individuals prepared to take up leadership responsibilities set themselves apart from peers and embark on the process of developing as authentic business leaders (Korngold, 2006).

Studies concentrated on existing and emerging leaders within the context of poultry business (Purcell, 2002) as well as leadership development and training of volunteer leaders in agrarian set ups have only occurred on a small scale (Mathews \& Carter, 2010; Carter \& Rudd, 2006). In tandem with a higher learning institution or other educational foundations, a number of regions and districts in Ghana have introduced formal leadership development agendas to train leaders in agriculture; nevertheless, these leadership initiatives concentrate largely on leadership skill development (Boateng, 2012). A few studies have been carried out to find out what motivates an individual to take up a leadership role, particularly leaders in non-formal leadership positions.

\section{CONCEPTUAL Framework}

Leadership is a contested topic, and as such, a concept that is difficult for scholars to define. Burns (1978) characterized two styles of leadership: transformational and transactional. Transactional leadership comes about when an individual takes the initiative to make a close interaction with others with the aim of an exchange of any object that is valued. Leaders will come closer to subordinates with a purpose on the exchange process. Burns (1978) held that transformational leaders have the capacity to nurture subordinates into leaders. Transformational leadership is different from transactional leadership as it is based on the subjective beliefs and values of the leaders and not on exchange of objects between the leader and subordinates (Kuhnert \& Lewis, 1987).

Bass (1985) described transactional leaders as individuals focused on accomplishment of organizational and personal outcomes and transformational leadership as top-quality leadership performance. Based on a subsequent comparison of transactional and transformational leadership, Bass (1990a, 1990b) discovered that transformational leaders to have better interpersonal relationships with supervisors, contribute more to organizational interests and are more effective leaders. Additionally, subordinates wield more power in support of transformational leaders than transactional leaders. Furthermore, transformational leaders are more likely to be perceived as effective managers than transactional leaders.

Barker (1997) alleged there was importance in concentrating on the capabilities and qualities of leaders. Accordingly, this would be useful and effective for leadership development and training agendas. Northouse (2010) described leadership as an influence process helping subordinates and individuals in attaining a common goal. Rost (2008) advocates that influence is when a leader will 
apply their capabilities to build positive relationships and produce collaborative and cooperative strategies. In this way, influence is viewed as the exercise of expert and referent power rather than coercion, reward and punishment.

Trait theories developed in the early twentieth century, and closely followed the idea that leaders were all great people. Stogdill's 1948 and 1974 research work (as cited in Northouse, 2010) were carried out to isolate qualities that set individuals in leadership positions apart from other people. Northouse (2010) reviewed the key character traits found in leadership studies to be integrity, intelligence, sociability, determination and self-confidence.

Focusing on behavior instead of character traits, Kouzes and Posner (2002) advanced a model of leadership deriving from their examination of transformational leadership in an effort to describe a leader. Kouzes and Posner (2002) developed a model with five essential practices of leadership model the way, inspire a shared vision, challenge the process, enable others to act, and encourage the heart.

The essay that started it all, The Servant as a Leader, Greenleaf (1977) inaugurated a leadership crusade in which great leaders are servants first. Greenleaf was writing with regards to a loss of trust in business leaders, proposing a practical approach that could aid set right the observed abuses of the corporate world. Servant leadership is radically different than the usual viewpoint studied. With servant leadership the emphasis is on (a) involving people in decision-making, (b) showing a caring attitude, (c) listening, understanding and broad communication skills, (d) interest in the growth of employees (followers), (e) persuasion, (f) ethical behavior, (g) intuition, and (h) the success and enhancement of the organization (Spears, 2010). Based on Greenleaf's (1977) earliest work, Spears (2010) found ten characteristics of a servant leader: Listening, acceptance and empathy, healing, awareness, persuasion, conceptualization, foresight, stewardship, commitment to growth of individuals and building community. Dirk van Dierendonck (2011, p.1232) distilled servant leadership attributes down to six major categories, described in the following manner: empower and develop people; they show humility, are authentic, accept people for who they are, provide direction, and are stewards who work for the good of the whole. Servant leadership offers abundant hope for the future in designing better, more caring, organizations.

A large majority of the research on leadership occurs within the discipline of organizational development, evaluating and measuring leadership in a business context where a leader has supervision over subordinates. Consequently, the vocabulary of leader and follower is applied as the foundation in researching and studying leadership. Transactional, transformational, and servant leadership are all focused around the everyday workplace environment. With scarce resources on leadership in a non- formalized context, the current study will open the door for more studies in this area.

\section{VOLUNTEER BUSINESS LEADERSHIP}

A volunteer is defined as a person who "recognizes a need and chooses to respond to it in ways that extend beyond basic social obligations, motivated by personal responsibility rather than monetary or other personal profit" (Garland, Myers, \& Wolfer, 2009, p. 23). Many non-profit organizations today, run on the efforts of volunteer workers (Boezeman \& Ellemers, 2014; Jager, Kreutzer, \& Beyes, 2009). Volunteers are hugely different than ordinary workers or employees. This is so because volunteers are not salaried or receive direct financial gains for work done (Boezeman \& Ellemers, 2014; Gaskin \& Smith, 1997; Pearce, 1983; Peters, 2010). Musick and Wilson (as cited in Handy \& Hustinx, 2009; McGruckin, 1998) observed that volunteerism is a kind of work since it requires specific capabilities and skills. Education was found to be the most important and reliable predictor of volunteering. However, other related factors were income, health, race, gender, occupation, and leisure time.

Further empirical studies investigating motivation and role of volunteers applied as a conceptual framework for the present research found the significance of volunteers: as a determining factor in a member's motivation to serve others (Carter \& Rudd, 2006; Van Til, 1988); goals corresponding to those of the organization (Jedlicka, 1990; Hinkle, Fox-Cardamonde, Haseleu, Brown, \& Irwin, 1996; Martinez \& McMullin, 2004); and the availability of an opportunity to provide their abilities and had the conviction that they have an obligation to serve their companies (Barry, 2015; Kajer as cited in Carter \& Rudd, 2005; United Nations Volunteer, 2011). 
Despite the fact that leadership has been widely explored and researched in the formal administrative development context, not much is known regarding leadership in non-formal membership based managerial contexts, where people are volunteer business leaders offering services for peers.

\section{Purpose}

The purpose of the present study was to explore poultry industry leaders in formal positions of membership based business organizations. The main research question was: What is volunteer business leadership to poultry sector leaders? To be more specific, the study aimed at researching the following sub-questions:

- How do poultry sector leaders define volunteer business leadership?

- How do poultry sector leaders describe the process to become a volunteer business leader?

- How do poultry sector leaders explain what motivated them to accept the leadership position?

\section{Methodology}

This study employed a qualitative methodology to investigate the experience of poultry industry leaders with the intention of understanding industry leadership within the poultry business. The study depended on interviews of identified persons applying open, wide-ranging questions to study the problem and learn from the respondents' experience, and how respondents give meaning to the experience (Plano-Clark \& Creswell, 2010; Richards \& Morse, 2007). The data was subsequently analyzed to establish emerging themes (Plano Clark \& Creswell, 2010; Saldana, 2011).

Since the purpose of the present research was to comprehend the real meaning of the experience of respondents (Hatch, 2002; Richards \& Morse, 2007); hence, a phenomenological qualitative study was preferred and selected from among the five qualitative study traditions proposed by Creswell (2007). All the study respondents shared the common experience as respondents were volunteer leaders serving and exercising various leadership roles within the poultry business organization. Moustakas' (1994) two fundamental questions to agree on the relevant model were applied as the groundwork to also decide on the motivation of the research as a phenomenological study. The current research sought to obtain a better insight into the meaning of leadership and what motivates individuals to accept leadership roles. Therefore, the phenomenological approach was the most appropriate for striving to describe and comprehend leadership within the poultry business.

To obtain a sample size that is acceptable for a qualitative study (Creswell, 2007; Plano-Clark \& Creswell, 2010; Polkinghorne, 1989; Richards \& Morse, 2007), 15 men and women currently serving in leadership functions within the poultry industry organizations were chosen to take part in the present research project. The people were purposefully selected. Applying standardized sampling procedures (Creswell, 2008), individuals selected shared common characteristics, as all respondents were leaders within a poultry business organization at the national level. These organizations comprised either the National Poultry Association or Regional Poultry Association such as the Ghana National Poultry Association. The number of leadership functions was not a deciding factor in choosing interview respondents; nevertheless, respondents had to be working in at least one board or committee to make similarity among all research respondents.

The yard stick to make a distinction between the respondents was based on maximal variation sampling (Creswell, 2007). Leaders who differed in gender, age, geographical setting, and industry sector were identified. The current research project was targeted for a balance of genders, even though we had to allow for the large number of men over women in the agricultural sector. Of the 15 research respondents, 11 were male and 4 were female. Respondents represented all the ten regions of Ghana. There were three representing the breeding and hatching eggs sector, two representatives from the poultry feeds division, three representing the village backyard production division, two representatives from the broiler production sector, and five representatives from the industrial and integrated production sector. Emphasis was put on choosing leaders who earned their living mainly through the poultry business and were currently engaged in production agriculture. All fifteen of the research respondents corresponded the key selection criteria.

A set of comprehensive questions was constructed for data gathering to obtain wide ranging answers from the research respondents (Plano-Clark \& Creswell, 2010; Richards \& Morse, 2007). The researcher carried out face-to-face interviews with each respondent. Each interview averaged 60 
minutes in duration, varying between 40 and 90 minutes. All respondents were probed based on the same six questions on the interview protocol and asked pre-set exploratory questions (Creswell, 2007). Further questions were only solicited to illuminate a point. The interviews were then transcribed for coding. Notes taken down during the interviews were also kept as a record. Gathering of data took place between March 2 and May 20, 2016.

Research respondents were invited to participate in the study through a personalized electronic mail describing the research project and then a follow up telephone call to establish their consent to be a respondent. The respondents were requested to sign the consent or agreement form and return it to the researcher. The researcher orally evaluated the agreement form with the respondent before carrying out the interview to ensure that the respondent did not have queries concerning the research project. All the fifteen respondents mailed back the consent form to the researcher.

\section{IDENTIFYING THEMES}

Important statements and essences concerning the phenomenon were examined carefully and described as the themes and what respondents experienced personally (Plano-Clark \& Creswell, 2010; Saldana, 2011). To categorize themes, the researcher read the fifteen word for word transcriptions a number of times to gain a general feeling for the information. Significant statements and expressions were singled out and coded to convey meanings and were grouped together by broad or generic themes (Moustakas, 1994). A thorough analysis of the data was performed to obtain a better insight into the key phenomenon. All the identified themes emerged directly from the interviews of the respondents. The transcriptions were then analyzed utilizing the MAXqda2 software program. This enabled the researcher to perform preliminary coding, highlight quotes and excerpts, and provide a rich, thick description of the responses of research respondent (Creswell, 2007; Saldana, 2011). Based on the manual coding for themes as well as the integration of the software analysis, the outcomes were integrated into a detailed account of the phenomenon.

\section{VALIDATING RESUltS}

Since the study was undertaken as a qualitative research, the emphasis was on gaining deeper insight into the information provided by the research respondents, instead of confirmation of a quantitative nature. Making reference to Creswell's (2007) eight strategies of authentication applied in qualitative studies, the researcher carried out elucidatory researcher bias and member-checking, by means of rich, thick descriptions as well as a peer review.

The researcher performed member checking of the information to authenticate the research results. All respondents were offered the opportunity to evaluate the transcripts for credibility and validity. Respondents were then asked to effect changes or provide additional information. Three of the respondents asked to have a copy of their interview transcripts for perusal. The rest of the respondents decided not to review the transcripts. From the three respondents who reviewed the transcripts, two of them approached the researcher with a few corrections in acronyms and spellings. The third respondent did not suggest any required changes. Respondent names were modified to pseudonyms and any personal data that could distinguish the respondent was eliminated or modified so that it is impossible to identify. The format of the current study did not make room for the respondents to review the other existing information and analysis devoid of violating confidentiality of the data.

Rich and in-depth descriptions were performed as a further data validation technique. Exhaustive respondent responses to the interview questions, as well as direct quotes, were presented in the findings section. At the last stage of the data analysis process, an essence was composed to expound the central phenomenon. That is, what the respondents personally experienced and how respondents experienced it. Finally, peer review was performed by an experienced academic researcher to give further validation to the interpretations of the themes as well as conclusions that emerged from the qualitative data.

\section{RESEARCH FINDINGS}

Based on the primary research question: What is volunteer business leadership to poultry sector leaders? Following the thematic analysis of transcripts as well as the researcher's notes, the interview data identified eight key themes:

- Be an active participant in the world of work.

- Represent the interest of the industry. 
- Be willing to make decisions

- Be a generous giver

- Giftedness in leadership

- Accepting challenges of greater responsibility at the appointed time.

- Chosen by fellow association members

- Be a role model.

Theme One: Be active participant in the world of work. The most common theme in the current study was respondents' deep desire and willingness to make a difference in the world of work. This idea was spoken about in a multitude of ways, as a number of respondents experienced volunteering as providing a sense of purpose in their lives, others communicated life not being all about oneself, while other respondents concentrate on the value of the influence and effect on others, and yet still other respondents spoke about improving the lives of people through either an experience comparable to theirs or assisting to delight in something they treasured. Every respondent interviewed spoke about making a difference in the world of work and the people around them. This emerged through a deep sense of purpose and meaning to do what is considered to be right, to offer service to others as one would like to be assisted, and to realize that a lot existed in the world than merely themselves. Several of the respondents expressed that one cannot become a leader if a person does not have a say in the future of the poultry business if one's voice is not heard. If people desire to be part of the decisions taken influencing the future of the poultry sector, then such individuals ought to be present for conversations and discussions.

Theme Two: Represent the interest of the industry. The respondents openly identified their pride for playing an important role in the poultry business and how genuinely they play this role of engaging with other producers to impact and improve the future of the poultry business in Ghana. Respondents have great expectations of poultry industry leaders, who stand for the common interest of the industry to the best of ability, but also for people who are willing to give first place to organizational goals. Some respondents anticipated this from themselves as they currently served in a leadership role, either on boards or committee level within the poultry farmers association of Ghana. The respondents thought that in order to have faith in a leader they must feel assured that the selected leader has the common interest of the entire poultry industry.

Theme Three: Be willing to make decisions. A number of respondents indicated that an important characteristic of volunteer business leadership is decisiveness, since people do not envision effective leaders who stand around looking doubtful, indecisive and blurred. Thus, respondents stressed the role of a volunteer industry leader as being a great decision-maker. Some respondents discussed the importance of a volunteer business leader who has the capacity to make decisions, even in the midst of hard or "wicked issues" to decide on. In an attempt to make tough decisions, volunteer poultry business leaders were characterized as individuals who must be able to see and grasp the big picture and navigate the association through uncertainties and turbulence. In principle, the volunteer industry leader is challenged to be "pushing the envelope". To be able to innovate and extend the existing limits of performance necessitates taking a bold stance and making hard decisions.

Theme Four: Be a generous giver. The poultry business sector has been described as a sector that frequently witness poultry farms and poultry businesses passed down from one generation to another within extended family households. However, four respondents explained that they did not grow up in the current occupation where they find themselves actively engaging for their living. Taking this experience into account, all of the respondents articulated the value of "giving back" something to the poultry industry. Devoting time and talent unreservedly to volunteering and contributing towards the improvement of the poultry business in Ghana made it possible for respondents to acquire more and innovative information, build network of relationships with other poultry producers, and benefited from the opportunity they would otherwise not have experienced in life.

Theme Five: Giftedness in leadership. The leaders described by the research respondents possessed character traits or leadership qualities that manifested similarity with many attributes and characteristics that made it possible to succeed as leaders. Character traits identified were integrity, respectful, knowledgeable, effective listeners and communicators, devotion, trustworthy and accountability. Respondents were depicting a leader with character and one who exhibited natural 
innate capabilities which gave real meaning to the leader. Such were the kind of leaders the research respondents turned eyes on, but also recognized the ordinariness of being truly human, with a blend of competencies leading to personal charisma. This made people within the poultry business sector to have confidence and trust in the leader.

Theme Six: Accepting challenges of greater responsibility at the appointed time. It was evident that being a volunteer leader was not on the "prioritized list" or "To-do list" of the current research respondents. Respondents did not make a thought-out list or keep a properly structured document with precise chronological sequence indicating that their goal was to become the chairman of the National Poultry Association of Ghana by 2015. Instead, respondents' elevation to leadership position happened through an entirely natural evolution, which many characterized "the appointed time". In most cases, respondents said leaders begun to become committed in the associations whether they were drafted or set out to volunteer for leadership responsibilities. As duty and devotion matured within the associations, they discovered their position and task increasing more and more towards leadership roles. This thematic category is closely aligned with the second minor question of the current research project: How do poultry sector leaders describe the process to become a volunteer business leader?

Theme Seven: Chosen by fellow association members. A number of research respondents stated how distinctive the leadership process is within the poultry business sector; the reason being that volunteer leaders are nominated by peer members. Within the mainstream traditional leadership set up, it is the responsibility and the sole prerogative of management board to select and appoint incoming leaders. It is not the case with the poultry business organizations, which are volunteer membership associations. Therefore, leaders are nominated by fellow association members to step into any leadership position, and asked to serve in the executive board or committee level. Once an individual is recruited into a leadership role, the person is expected to work together with peers to come out with concrete decisions. And even though the overall responsibility of providing leadership rests on the leader, the central difference in scope of authority and influence as perceived within the old style, longestablished leader-follower context does happen with peer volunteer leaders.

Theme Eight: Be a role model. Role models demonstrate passion for their job and have the ability to "infect others" with that passion. Majority of respondents indicated that one of the most important qualities of an effective leader is to maintain a respected, leadership role model, to be the kind of person that all and sundry looks up to and desires to be like. A critical quality of a person in a leadership position is that they are able to carry themselves all the time, even when nobody is observing, as if the whole world was watching. According to respondents interviewed for the present study, each leader must demonstrate high ethical standards, to show to their peers as well as to other stakeholders that they are decent and resolved to do their best for the industry. As expressed by one respondent, "leaders live in a goldfish bowl". As a result, each and every one is watching the man or woman in the leadership role. Effective leaders are aware of the impact of their gestures and words on the people around them. Respondents advised that a leader should always be sensitive to the fact that whatever a person says or does is amplified times the people who are accountable to you (peers and subordinates) or look up to you for guidance and direction.

\section{Characteristics of a Poultry Business Leader}

The second objective of the present research project was to find out how poultry business leaders described business leadership. The first sub-question concentrated on investigating to understand how respondents perceived business leadership. The respondents were invited to describe a leader. Answers given included expressions or catchphrases like (a) forward thinking mind-set, (b) available to serve others, (c) well-informed, (d) take full responsibility, (e) accept the outcomes of all decisions, (f) true to who you are deep inside, (g) active listener, (h) effective communicator, (i) emotional expressiveness, and, (j) ability to relate and work with people. Respondent' characterizations of the great leader showed an individual with integrity and moral fibre; a person who respondents would be impressed to exclaim represents their company. The respondents model themselves on leaders who were considerate, humble and represented the poultry industry business the best they could. These qualities enabled respondents to have confidence in the leaders, go along with them, and have trust in their power to take the right decisions and stand up for those decisions. 
The personality characteristics identified in the study were summarized into five character traits of a poultry business leader. Arranged according to the emphasis placed by the respondents those character traits are:

- Desire to serve others

- Be a person of high level integrity

- Effective communicator

- Mindful decision maker

- Being a team player/investing in others

Characterizing these personality characteristics of poultry industry leaders also provided clear understanding into the fifth thematic category of the overall study - giftedness in leadership.

\section{IDENTIFYing SourCES OF Motivation}

The third research objective focused on identifying the source of motivation to take up a leader position. The third minor research question inquired, "How do poultry sector leaders explain what motivated them to accept the leadership position?" The most common responses were "to contribute towards the growth of the industry", "the poultry business is my primary source of livelihood" and because "they are full of pride for the poultry business as agriculturalists." Respondents were motivated to become volunteer leaders because they wanted "to get totally involved and represent the collective voice on critical issues and out of concern for the future of the poultry business" and "it is an industry I am passionate about, therefore I want to contribute to make it better for posterity."

The respondents were moved and inspired by a purpose. That is, the motivation to speak up for the industry where they depend on for a decent living, to secure a future for the next age bracket, to stand up against external influences that could be a threat for the downfall of the industry or for the reason that their poultry farms have been in the family for many years, and feeling of personal worth has been inculcated in them to produce safe, healthy sustenance. A sense of personal value originated a purpose as well as interest. If these peer, volunteer leaders did not collaborate and work for the poultry industry, then who else would? A number of the leaders were motivated and reassured by mentors, others possessed leadership competences and skills introduced to them during the time of national service, while some might have observed leaders who they deeply revered.

\section{CONCLUSIONS}

This qualitative, phenomenological study sought to investigate the leadership qualities common in poultry business leaders, identify motivators and impacts of the persons serving in leadership positions for their associations, and also examine the structure of the poultry business and how people become leaders in such a context. The researcher constructed a generic and broad definition of volunteer business leadership based on the data collected from respondents. To be exact, "an executive role performed by an individual or group of persons, who unreservedly devote time and talent contributing to the greater good of the industry, accepting challenges of greater responsibility particularly with regard to decision-making, and representing members with honesty and fairness."

The present study identified leader personality attributes similar to characteristics found in traits perspective research carried out by Stogdill (as cited in Northouse, 2010) and were strongly related to the five key traits identified by Northouse (2010). The respondents frequently talked about respect, gaining respect, and showing respect towards others. Northouse suggests integrity promotes respect and the present research data indicate poultry business leaders share the same point of view.

Research respondents depicted poultry business leaders as persons who start at the grassroots level, an attribute in agreement with servant leadership (Greenleaf, 1977; 1991). Respondents began their interest and engagement in leadership through volunteering and becoming effective at the district level with poultry membership associations, and getting better prepared to be leaders based on the skills and experiences they acquired. As the respondents talked about their notions of leadership, respondents linked corresponding views to Spear's (2010) characterization of servant leaders, which involves concentrating on other people in the decision making practice, exhibiting ethical and a caring attitude, as well as showing great interest in the advancement and success of the business. 
Barbuto and Wheeler (2006) described servant leadership as consisting of 11 attributes built on the more influential works of Greenleaf (1997) and Spears (2002). The altruistic dimension of servant leadership (Barbuto \& Wheeler, 2006) was identified as a person's desire and readiness to serve others, which is directly associated to the first thematic category identified in the present study, "Be an active participant in the world of work." Poultry business leaders are eager to serve their companies and they do so based on the conviction and love for the poultry business. This commitment expresses an aspect of servant leadership. The respondents' concern for providing services due to their self-sacrificing calling was also consistent with what scholars established as to why people volunteer. Empowered volunteers, according to Peters (2010) have a desire to make a difference in the world. This view is corroborated by the findings from the current study, where poultry business leaders were emboldened to volunteer and stand for the poultry industry to the best of their ability, reminiscing that the capacity to lead influenced not only the poultry industry but the sustainability of the businesses of others.

\section{IMPLICATIONS}

Agrarian industry associations, which are predominantly membership-based, are designed to offer members with a judicial or legislative voice at the local, regional and national level, as well as influence public policy (Abaru, et al., 2005; FAO, 2014; Owusu-Afari, 2010). Volunteer poultry leaders take up leadership roles on management boards and committees to represent associations. The present study provides significance to the discipline of leadership, to the poultry business sector, and by implication to agricultural organizations. The poultry business sector is a sustainable economic driver for the Ghanaian economy in several ways (FAO, 2014). Poultry producers depend on poultry production for their source of income and general livelihood, and consumers depend on poultry products for nutritional requirements. A deeper and broader understanding of volunteer, poultry business leadership will give support and direction to establishments and associations who depend on peer leaders to be representatives, facilitators and decision-makers of their industry sectors, on production, social, economic and legislative matters.

The outcomes of the current study can provide useful implications in the fields of leadership and poultry sector leadership development. For instance, changing leadership from one age bracket to the next, staffing and development, educational leadership coaching, interpretation of roles for volunteer leaders, the arrangements involved for volunteers to serve as leaders, a better understanding of nonformalized leadership structure, and the role played by peer leaders in membership-based agricultural associations.

The insights obtained from this research project will be most useful to associations managed by volunteer leaders nominated and assigned by peer members. The current study provides an important contribution to the domain of research on volunteer leadership. Volunteer leadership is incomparable to the more frequently explored leadership in formalized contexts including the corporate business environment, and the present study helps clarify why people are inclined to accept peer leadership roles and the prospects of serving in a peer leadership responsibility.

This research project specifies a research groundwork for poultry business leaders with reference to the trait-based perspective of leadership, the styles of leadership, motivational basis, as well as, general framework of what is volunteer, poultry business leadership. Other agricultural-based associations could include some of the aforesaid fundamentals examined and learned in the present study into their organizational arrangement to help in selecting, training, and retaining leaders.

\section{REFERENCES}

[1] Abaru, M.B., Kabuga, C., \& Masake, R. (2005). Leadership for change in Farmers Organizations. Training report: Ridar Hotel, Kampala, 29th March to 2nd April, 2005. ICRAF Working Paper - no 4. Nairobi: World Agroforestry Centre.

[2] Adei, D., \& Asante, B. K. (2012). The challenges and prospects of the poultry industry in Dormaa District. Journal of Science and Technology (Ghana), 31 (1), 104-116. http://dx.doi.org/10.4314/just.v32i1.11

[3] Aning, K.G. (2006). The structure and importance of commercial and village based poultry in Ghana. Final Review, 18-27.

[4] Asare-Boadu, K. (2010). High Production Cost killing Poultry Industry. Modern Ghana News. Available at http://www.modernghana.com/news/230092/1/high-production-costkilling-poultryindustry.html 
[5] Barry, Z.P. (2015). An investigation into the leadership practices of volunteer leaders. Leadership \& Organization Development Journal, $36 \quad$ (7), 885 - 898. http://dx.doi.org/10.1108/LODJ-03-2014-0061

[6] Barbuto, J. E., \& Wheeler, D. W. (2006). Scale development and construct clarification of servant leadership. Group \& Organization Management, 31(3), 1-27.

[7] Barker, R. A. (1997). How can we train leaders if we do not know what leadership is? Human Relations, 50, 343-362.

[8] Bass, B. M. (1985). Leadership and performance beyond expectations. New York: Free Press.

[9] Bass, B. M. (1990a). Handbook of leadership: Theory, research, and applications (3rd ed.). New York: Free Press.

[10] Bass, B. M. (1990b). From transactional to transformational leadership: Learning to share the vision. Organizational Dynamics, 18(3), 19-31.

[11] Boateng, C. (2012). Restructuring vocational and technical education in Ghana: The role of leadership development. International Journal of Humanities and Social Science, 2 (4), 108-114.

[12] Boezeman, E.J., \& Ellemers, N. (2014). Volunteer leadership: The role of pride and respect in organization identification and leadership. Leadership, 10(2), 160-173. Doi: $10.1177 / 1742715012467487$.

[13] Burns, J. M. (1978). Leadership. New York: Harper \& Row.

[14] Carter, H. S., \& Rudd, R. D. (2005). Proceedings of 2005 National AAAE Research Conference, Factors Which Influence Leadership Participation in Agricultural Organizations (pp.483-496). San Antonio.

[15] Creswell, J. W. (2007). Qualitative inquiry and research design: Choosing among five approaches. Thousand Oaks, CA: Sage.

[16] Creswell, J. W. (2008). Educational research: Planning, conducting and evaluating quantitative and qualitative research. Upper Saddle River, NJ: Pearson Education.

[17] Darko, K. (Wednesday, October 20, 2010). Ghana's Poultry Industry Still Faces Challenges. GHANA - The Government has been urged to revive the Poultry Industry. Poultry Site News. Available at www.thepoultrysitelatestnews.com/Ghana's Poultry Industry Still Faces Challenges.

[18] FAO (2014). Poultry Sector Ghana. FAO Animal Production and Health Livestock Country Reviews. No. 6. Rome.

[19] Field, T. (2008). Now's the time for leadership, data. Vision in Action conference. Retrieved fromhttp://www.limousinlive.com/2008/12/field-nows-thetime-for-leadership-data/

[20] Garland, D. R., Myers, D. R., \& Wolfer, T. A. (2009). Protestant Christian volunteers in community social service programs: What motivates, challenges, and sustains their service. Administration in Social Work, 33(1), 23.

[21] Gaskin, K. \& J. D. Smith (1997). A New Civil Europe? A study of the extent and role of Volunteering (The National Volunteering Centre, London).

[22] Greenleaf, R. K. (1977). Servant Leadership: A journey into the nature of legitimate power and greatness. New York: Paulist Press.

[23] Greenleaf, R. K. (1991). The servant as leader. Indianapolis: Robert K. Greenleaf Center. Retrieved from http://www.greenleaf.org/catalog/Introduction_to_Servant_Leadershp .html

[24] Handy, F., \& Hustinx, L. (2009). The why and how of volunteering. Non-profit Management \& Leadership, 19(4), 549-558.

[25] Hatch, J. (2002). Doing qualitative research in educational settings. Albany, NY: State University of New York Press.

[26] Hejny, T. A. (2010). Discovering the leadership skills of alumni who participated in an adult agricultural leadership development program: A case study. Retrieved from http://digitalcommons.unl.edu/cehsdiss/89

[27] Hinkle, S., Fox-Cardamonde, L., Haseleu, J. A., Brown, R., \& Irwin, L. (1996). Grassroots political action as an intergroup phenomenon. Journal of Social Issues, 52(1), 39-51.

[28] Jager, U., Kreutzer, K., \& Beyes, T. (2009). Balancing acts: NPO-leadership and volunteering. Financial Accountability \& Management, 25 (1), 79-97. 
[29] Jedlicka, A. (1990). Volunteerism and world development: Pathway to a new world. New York, NY: Greenwood Publishing Group.

[30] Kellogg Foundation (W. K.) (1993). Grassroots leadership development: A guide for grassroots leaders, support organizations and funders. Retrieved from http://www.wkkf.org /knowledgecenter/resources/2003/01/Grassroots-Leadership-Development-A-GuideForGrassroots-Leadership-Support-Organizations-And.aspx

[31] Korngold, A. (2006). Developing visionary leaders. Leader to Leader, 40, 45-50.

[32] Kouzes, J. M., \& Posner, B. Z. (2002). The leadership challenge. (3rd ed.). San Francisco: Jossey-Bass.

[33] Kuhnert, K. W., \& Lewis, P. (1987). Transactional and transformational leadership: A constructive/developmental analysis. Academy of Management Review, 12(4), 648-657.

[34] Mathews, C., \& Carter, H. (2010). Proceedings of Association of Leadership Educators (ALE): 2010 ALE Annual Conference Proceedings. Milwaukee, WI.

[35] Martinez, T. A., \& McMullin, S. L. (2004). Factors affecting decisions to volunteer in nongovernmental organizations. Environment and Behavior, 36(1), 112-136.

[36] McGruckin, F. (1998). Volunteerism. New York, NY: The H.W. Wilson Company.

[37] Moustakas, C. (1994). Phenomenological research methods. Thousand Oaks, CA: Sage National 4-H Organization (2011).

[38] Northouse, P. G. (2010). Leadership, theory and practice (5th ed.). Thousand Oaks, CA: Sage.

[39] Oppong-Apane, K. (2013). Cassava as Animal Feed in Ghana: Past, Present and Future. (Ed) by Bedane, B., Cheikh Ly and Makkar, H.P.S. FAO, Accra, Ghana.

[40] Otoo, J. (2009). Crisis in Ghana's Poultry Industry. Ghana Business News. Available at www.moderghana.com/ Crisis in Ghana's Poultry Industry.

[41] Owusu-Afari, E. (2010). Ghana - Problems in Poultry Industry. Meat Trade News Daily. Available at www.meattradenewsdaily.co.uk/ Ghana - Problems in poultry industry

[42] Pearce, J.L. (1993) Volunteers: The organizational behaviour of unpaid workers. London/New York: Routledge.

[43] Peters, A. K. (2010). The lived experience of empowered volunteers: A study of Christianchurch volunteers. Retrieved from http://digitalcommons.unl.edu/aglecdiss/7/

[44] Plano-Clark, V. L., \& Creswell, J. W. (2010). Understanding research: A consumer's guide. Saddle River, NJ: Merrill.

[45] Polkinghorne, D. E. (1989). Phenomenological research methods. In R. S. Valle \& S. Halling (Eds.), Existential-phenomenological perspectives in psychology (pp. 41-60). New York: Plenum.

[46] Ragasa, C. \& Golan, J. (2012). The role of rural producer organizations for agricultural service provision in fragile states. IFPRI Discussion Paper 1235. Washington, D.C.: International Food Policy Research Institute (IFPRI). http://ebrary.ifpri. org/cdm/ ref/ collection /p1573 8coll2 /id/127327

[47] Rost, J.C. (2008). Influence. In A. Marturano and J. Gosling, J. (eds), Leadership: The Key Concepts. Abingdon: Routledge, 86-90.

[48] Richards, L., \& Morse, J. M. (2007). Readme first for a user's guide to qualitative methods (2nd ed). Thousand Oaks, CA: Sage.

[49] Saldana, J. (2011). Fundamentals of qualitative research. New York: Oxford University Press.

[50] Spears, L. C. (2002). Introduction: Tracing the past, present and future of servant leadership. In L. C. Spears (Ed.), Focus on leadership (pp. 1-18). New York: John Wiley.

[51] Spears, L. C. (2010). Character and servant leadership: Ten characteristics of effective, caring leaders. The Journal of Virtues and Leadership, 1(1), 25-30.

[52] Speer, N. C. (2008). 2008 in review. CALF News, 47, 6.

[53] Sumberg, J., Awo, M., Fiankor, D-D. D., Kwadzo, G.T-M. \& Thompson, J. (2013). Ghana's Poultry Sector: Limited Data, Conflicting Narratives, Competing Visions, STEPS Working Paper 56, Brighton: STEPS Centre 
[54] United States Department of Agriculture (USDA). (2011). Poultry and Products Brief Annual Gain Report (Number GH8007). Ghana, Nigeria: Foreign Agricultural Service, USDA.

[55] United Nations Volunteer (2011). State of the world's volunteerism report. Universal values for global wellbeing. Retrieved from http://www.unv.org /fileadmin/ docdb/ pdf/2011/ SWVR/ English/SWVR2011_full.pdf

[56] Van Dierendonck, D. (2011). Servant leadership: A review and synthesis. Journal of Management, 37 (4), 1228-1261.

[57] Van Til, J. (1988). Mapping the third sector, Volunteerism in a changing economy. Journal of Voluntary Action Research, 16(3), 43-53.

\section{AUTHORS' BIOGRAPHY}

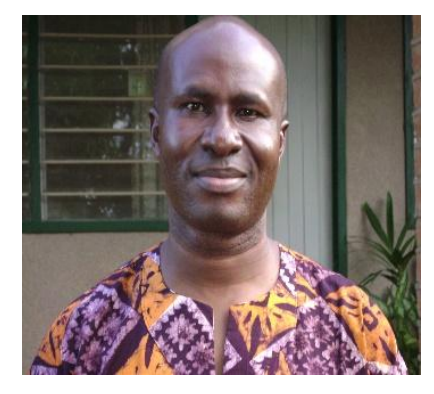

Dr. Remy Nyukorong is General Treasurer of Stichting Kongregatie F.I.C., headquartered in the Netherlands. $\mathrm{He}$ is, at the same time, the Executive Director of Management Partners $(\mathrm{GH})$, a professional management consulting firm in Ghana, whichfocuses onproviding strategic, substantial, and pragmatic advisory services topublic and private organizations and businesses to produce positive change and increase organizational effectiveness, by identifying issues and problems, and recommending ways to improve operations. He holds a Doctorate of Business Administration from Swiss Management Center University, (Switzerland), an MBA (Accounting \& Finance) from Maastricht School of Management(The Netherlands), and a BSc. (Hons.) degree in Education from St. Mary's University of Minnesota, USA (Nairobi campus, Kenya). He was a lecturer for several years at the Wa Polytechnic Business School in the Upper West Region of Ghana. His research interestsare in the areas of leadership, organizational behavior, innovation \& entrepreneurship, marketing, finance and investment management. 